Widodo, M.M., \& Ruhaena, L. (2018). Lingkungan Literasi di Rumah pada Anak Pra Sekolah. Indigenous: Jurnal Ilmiah Psikologi, 3(1), 1-7. doi:https://doi.org/10.23917/indigenous.v3i1.3059

\title{
Literasi di Lingkungan Rumah pada Anak Pra Sekolah
}

\author{
Mulyo Manggih Widodo ${ }^{1}$,Lisnawati Ruhaena ${ }^{2}$ \\ Universitas Muhammadiyah Surakarta ${ }^{12}$ \\ mulyo.manggih.w@gmail.com ${ }^{1}$ lisnawati.ruhaena@ums.ac.id ${ }^{2}$
}

\begin{abstract}
Abstraksi. Penelitian ini bertujuan untuk memahami, dan mendeskripsikan literasi di lingkungan rumah pada anak pra sekolah. Penelitian ini merupakan penelitian kualitatif deskriptif dengan menggunakan kuesioner terbuka untuk mengumpulkan data. Informan pada penelitian ini berjumlah 54 informan yang diambil dengan purposive sampling. Hasil penelitian ini menunjukkan bahwa (1) literasi di lingkungan rumah pada anak pra sekolah terdiri dari kesadaran orangtua akan pentingnya pengajaran literasi sejak dini, yaitu kebiasaan orangtua dalam melakukan kegiatan literasi sebagai kegiatan yang dilakukan sehari-hari sehingga aktivitas itu juga diterapkan kepada anak usia pra sekolah, kegiatan yang dilakukan orangtua dan anak dilakukan secara bersama-sama dan interaktif dan didukung oleh bahan atau kelengkapan alat yang dapat membantu berkembangnya kemampuan literasi anak. (2) Faktor pendukung literasi dirumah yang ditemukan peneliti pada penelitian ini adalah berupa kesadaran orangtua akan pentingnya kemampuan literasi awal di lingkungan rumah, aktivitas sehari-hari yang dilakukan oleh informan, kebiasaan membaca bersama, kelengkapan bahan literasi dirumah berupa buku cerita, alat tulis, mainan, dan kegiatan bersama anak yang mendukung literasi dirumah. (3) Faktor penghambat dalam mengajarkan literasi dirumah yang ditemukan peneliti: pendapatan keluarga yang mayoritas rendah, keterbatasan bahan bacaan informan dan suami dirumah serta keterbatasan bahan pendukung literasi dirumah yang disediakan oleh informan..
\end{abstract}

Kata kunci: anak usia dini, baca tulis, prasekolah

\section{PENDAHULUAN}

Sejak lahir sampai usia 3 tahun anak memiliki kepekaan sensoris dan daya pikir yang sudah mulai dapat menyerap pengalamanpengalaman melalui sensori-nya. Anak usia satu setengah tahun sampai kira-kira 3 tahun sudah mulai memiliki kepekaan bahasa dan sangat tepat untuk mengembangkan bahasanya. misalnya berbicara, bercakap-cakap. (Theo \& Martin, 2004).

Masa emas perkembangan anak yang hanya datang sekali seumur hidup tidak boleh disiasiakan. Hal itu yang memicu makin mantapnya anggapan bahwa sesungguhnya pendidikan yang dimulai setelah usia SD tidaklah benar. Pendidikan harus sudah dimulai sejak usia dini supaya tidak terlambat. Hal penting yang diperlukan dalam proses pendidikan, salah satunya adalah terkait kemampuan membaca dan menulis. Sehingga penting bagi anak untuk mendapatkan pendidikan baca tulis di usia dini (Martini, 2006).

Fenomena siswa gagal ujian nasional mata pelajaran bahasa Indonesia di tahun 2010 memperlihatkan rendahnya pemahaman membaca pada anak-anak Indonesia. Studi Progress in International Reading Literacy Study (PIRLS) memperlihatkan minat membaca siswa SD Indonesia termasuk kategori rendah. Studi PIRLS tahun 2006 memperlihatkan posisi Indonesia di nomor 41 dari 45 negara. Demikian pula hasil penelitian Programme for International Student Assesment (PISA) menempatkan siswa Indonesia pada posisi 48 dari 56 negara di dunia di tahun yang sama dengan skor rata-rata 393. Minat baca rendah inipun terulang di tahun 2009, hasil penelitian PISA menempatkan posisi membaca siswa Indonesia di nomor 57 dari 65 negara dunia, dengan skor rata-rata 402 sementara rerata internasional 500 (Agung, 2012). 
Peran aktif orang tua terhadap perkembangan anak - anaknya sangat diperlukan terutama pada saat ia masih berada dibawah usia lima tahun atau balita. Orang tua salah satunya adalah ibu, merupakan tokoh sentral dalam tahap perkembangan seorang anak. Ibu berperan sebagai pendidik pertama dan utama dalam keluarga sehingga ibu harus menyadari untuk mengasuh anak secara baik dan sesuai dengan tahapan perkembangan anak (Hidayat, 2008).

Hasil penelitian Rifa Hidayah menunjukkan bahwa lingkungan sosial yang berpengaruh paling kuat terhadap pemahaman membaca adalah literasi di lingkungan rumah $(22,2 \%)$, dan keterlibatan orang tua dan literasi di lingkungan sekolah lebih rendah $(4,4 \%)$. Sementara faktor kognitif metakognisi memiliki pengaruh yang tinggi $(11,2 \%)$ dan motivasi membaca $(4,9 \%)$. Kuatnya potensi literasi di lingkungan rumah yang memprediksi pemahaman membaca pada anak dapatlah dipahami, karena lingkungan rumah adalah lingkungan yang paling akrab dan dekat dengan anak. Anak lebih banyak berinteraksi di rumah bersama keluarga dibandingkan interaksi di sekolah (Agung, 2012).

Menurut Katz (1997) Anak yang mendapat dukungan dan bantuan yang baik dari orangtuanya akan bisa belajar dan mencapai kemajuan lebih baik dibanding anak yang tidak mendapat dukungan dan bantuan dari orangtuanya. Anak-anak yang diajarkan orangtua melalui percakapan yang beragam, memiliki kesempatan untuk mendengar, mempraktekannya serta menanggapi berbagai pertanyaan yang bersifat terbuka, beragam percakapan mengacu pada penggunaan berbagai bentuk bahasa dalam berbagai fungsi komunikatif seperti menstimulasi anak untuk bertanya dan bermain.

Penelitian yang dilakukan oleh Sadr, dkk, (2015) merupakan penelitian yang bertujuan untuk menguji hubungan antara literasi di lingkungan rumah dengan kemampuan literasi awal pada 90 anak usia 3 hingga 4 tahun di negara Iran, dan hasil penelitian tersebut terdapat hubungan yang signifikan antara literasi di lingkungan rumah dengan kemampuan literasi awal pada anak-anak prasekolah di Iran.
Roberts, Jurgens, dan Burchinal (2005) menyelidiki kegiatan keaksaraan rumah di antara Ibu di negara Afrika-Amerika dengan anak usia 3 sampai 5 tahun. Penelitian ini menguji empat pengukuran praktik keaksaraan rumah antaralain membaca buku cerita membaca bersama, kebiasaan atau gaya ibu dalam membaca buku, menikmati membaca buku, dan kepekaan ibu serta pengukuran secara umum terhadap kualitas literasi di lingkungan rumah selama usia pra sekolah dalam memprediksi kemampuan berbahasa dan keaksaraan awal. Dalam penelitian ini mendapatkan temuan bahwa literasi di lingkungan rumah dapat berkontribusi dalam kemampuan berbahasa dan keterampilan keaksaraan awal pada anak-anak Afrika-Amerika.

Melihat berbagai fenomena tersebut, membuktikan bahwa pembekalan literasi perlu dilakukan sejak dini agar anak mendapatkan pembekalan sedini mungkin sehingga mengurangi resiko hambatan dalam bahasa. Dari berbagai penelitian terdahulu yang menunjukkan literasi di lingkungan rumah pada anak pra sekolah, peneliti belum menemukan penelitian terdahulu mengenai literasi di lingkungan rumah pada anak pra sekolah di Indonesia, sehingga peneliti menekankan pentingnya hal ini untuk menemukan keunikan tersendiri pada anak prasekolah serta faktor pendukung dan penghambat yang ada di Indonesia. Berdasarkan data-data diatas yang menunjukkan pentingnya pembekalan literasi sejak usia dini di lingkungan rumah, maka peneliti ingin mengetahui lebih dalam tentang faktor-faktor lingkungan rumah apa saja yang dapat mendukung dan penghambat dalam pengembangan kemampuan literasi anak pra sekolah. Harapannya penelitian ini dapat dijadikan bahan pertimbangan untuk dapat mengoptimalkan kegiatan literasi bersama anak dirumah.

Secara tradisional, Burges (2000) menuliskan bahwa literasi di lingkungan rumah diartikan sebagai tingkat frekuensi membaca buku bersama antara orangtua dan anak-anak. Namun, hal ini dianggap terlalu sederhana dan tidak mewakili faktor penting yang ada di dalam literasi di lingkungan rumah. Oleh karena itu, Schmitt dkk, (2011) berpendapat 
bahwa literasi di lingkungan rumah secara luas merupakan aneka pengalaman yang terjadi secara interaktif di beberapa konteks keaksaraan dan sering disebut sebagai komponen kunci dalam munculnya kemampuan literasi awal.

Literasi di lingkungan rumah adalah wadah yang memfasilitasi bertemunya bahasa dan keaksaraan untuk pertamakali, misalnya anakanak pertama kali memperoleh pengalaman dengan buku di lingkungan rumah dengan mengamati orangtua membaca atau saat membaca bersama (Bus dkk, 1995).

Umek (2005) mengklasifikasikan literasi di lingkungan rumah kedalam lima faktor:

a. Memberikan stimulasi dan penjelasan kepada anak dalam penggunaan bahasa.

b. Membacakan kepada anak menggunakan buku cerita, mengajak anak mengunjungi perpustakaan dan mengajak anak melihat teater boneka.

c. Anak dilibatkan dalam berbagai kegiatan dan percakapan.

d. Orangtua atau keluarga membiasakan anak untuk diajak dalam membaca secara interaktif.

e. Stimulasi zona perkembangan proksimal

Merupakan stimulasi perkembangan kognitif anak melalui tugas yang diberikan oleh pembimbing di dalam lingkungan/ kebudayaan yang memiliki nilai.

Selain pendapat Umek, faktor-faktor yang mempengaruhi kemampuan literasi dirumah adalah:

a. Status sosial ekonomi, (Duncan dkk, 1998)

Diwakili oleh pendapatan keluarga dan tingkat pendidikan orangtua digunakan sebagai karakteristik untuk menentukan kemampuan keuangan dan mempengaruhi keinginan dan kesempatan yang tersedia untuk anak.

b. Struktur keluarga (Mcloyd, 1990), Struktur keluarga mempengaruhi keaksaraan dirumah. Anak-anak yang tinggal bersama orangtua tunggal lebih cenderung berada di dalam kemiskinan dan beresiko tinggi mengalami keterlambatan perkembangan.

c. Lokasi tempat tinggal (Fuller dkk, 1996) Karakteristik lingkungan tempat tinggal dapat memberikan pengaruh terhadap hasil belajar anak-anak dalam memberikan fasilitas.

d. Komputer, Tablet dan Smartphone (Haugland, 2000)

Haugland menekankan bahwa anak usia tiga hingga empat tahun menggunakan komputer, tablet dan smartphone, menunjukkan kelebihan pada penggunaan bahasa verbal, kemampuan memecahkan masalah, berfikir secara abstrak dan kemampuan merekam dalam memori jangka panjang dibandingkan dengan anakanak yang tidak menggunakan komputer, tablet dan smartphone.

e. Media Informasi Internet (Nursila, 2013) Internet dapat dimanfaatkan untuk memupuk semangat belajar secara mandiri pada anak, misalnya dengan memanfaatkan software yang menarik untuk menggugah minat anak belajar. Isi atau materi pelajaran yang menarik diharapkan dapat menciptakan suasana belajar yang penuh dengan kegembiraan. Sekaligus menghindarkan anak dari rasa tertekan saat belajar karena menganggap pelajaran sulit dan menakutkan, dan sebagainya.

Menurut Burgess (2002), aspek literasi di lingkungan rumah dikategorikan secara aktif, pasif, interaktif dan keseluruhan pengukuran dari perilaku di dalam literasi di lingkungan rumah :

1. literasi di lingkungan rumah secara aktif merupakan keterlibatan orangtua dalam mendukung kegiatan anak-anak yang bertujuan untuk mengembangkan keterampilan berbahasa dan keaksaraan (aktivitas literasi) seperti membaca bersama dan melakukan permainan yang memiliki irama.

a. Jumlah buku bacaan yang dimiliki oleh anak,

b. Seberapa sering menggunakan huruf magnet

c. Frekuensi membaca bersama.

2. Lingkungan literasi dirumah secara pasifmerupakan"pembelajaran langsung secara modeling" literasi di lingkungan rumah secara pasif untuk mengetahui :

a. Kesenangan orangtua dalam membaca, 
b. Jumlah buku dan majalah yang dimiliki oleh keluarga,

c. Seberapa sering orang tua memanfaatkan fasilitas perpustakaan,

d. Frekuensi orangtua menonton televisi

3. "Limitting environment"

a. Tingkat pendidikan orangtua

b. Tingkat ekonomi orangtua

Adapun yang menjadi pertanyaan penelitian adalah 1. Bagaimana lingkungan literasi di rumah?; 2. Faktor-faktor apa saja yang dapat mengembangkan kemampuan literasi anak prasekolah?; 3. Faktor-faktor apa saja yang dapat menghambat kemampuan literasi anak prasekolah?

\section{METODE PENELITIAN}

Metode yang digunakan dalam penelitian ini adalah metode kualitatif. Penelitian ini menggunakan metode kualitatif deskriptif yang bertujuan untuk memperoleh informasi, melalui kuesioner terbuka, mengenai pengetahuan Ibu mengenai faktor-faktor yang pendukung dan penghambat literasi yang ada di rumah yang mencakup bagaimana gambaran pentingnya literasi, bagaimana aktivitas literasi di rumah, kelengkapan bahan pendukung, serta kegiatan yang biasa dilakukan di rumah. Penelitian ini dilakukan di daerah Sukoharjo dan sekitarnya yang meliputi: Karangasem, Gonilan, Mendungan, dan Nilasari, Sukoharjo. Informan dalam penelitian ini dipilih secara purposive sampling yaitu pemilihan informan dengan menggunakan kriteria ataupun ciri-ciri yang telah ditentukan sebelumnya. Ciri-ciri informan dalam penelitian ini antara lain:

1. Seorang Ibu

2. Memiliki anak pra sekolah usia 3-5 tahun

Angket terbuka diberikan kepada 54 informan yang memiliki anak pra sekolah Sebelum itu, peneliti menanyakan kesediaan setiap informan untuk diwawancarai dengan memberikan informed consent sebagai bentuk pertanggung jawaban peneliti kepada informan tentang kerahasiaan data informan.Semua informan bersedia untuk mengisi angket terbuka tersebut. Kunjungan ke rumah informan dilakukan selama dua kali, yang pertama adalah permohonan kesediaan dan peneliti menitipkan angket ke informan, keesokan harinya peneliti mengunjungi rumah informan untuk mengambil angket terbuka tersebut. Peneliti menggunakan analisis tematik sebagai salah satu teknik dalam analisis kualitatif yang memilah dan mengkode informasi dari responden dalam bentuk tema-tema khusus. Tema tersebut dapat berupa daftar tema, model tema, atau kualifikasi yang berkaitan dengan tema tersebut. dengan menggunakan teori dan penelitian sebelumnya.

\section{Kesadaran Orangtua akan pentingnya literasi awal}

Sebagian besar informan setuju bahwa pembelajaran anak mengenai baca tulis sejak usia dini penting untuk dilakukan, harapan orangtua agar anak dapat mengenal huruf dan angka sedini mungkin penting untuk dilakukan dengan tujuan untuk memperkaya perbendaharaan kata dari anak, dapat merangsang motorik kasar dan halus pada anak serta dapat menjadikan salah satu usaha yang dilakukan oleh orangtua agar kecerdasan anak dapat dioptimalkan sehingga terbentuk kemampuan baca tulis anak sebelum ia memasuki usia sekolah formal.

Informan dalam penelitian ini memberikan pendapat mengenai kemampuan membaca dan menulis sejak dini dianggap penting untuk diajarkan pada anak usia dini serta berpengaruh terhadap kecerdasan anak. Hal ini serupa dengan teori yang dikemukakan oleh Hasan (2008) kemampuan membaca dan menulis di awal tahap masa prasekolah atau literasi awal memiliki peranan penting dalam kehidupan seorang anak, terutama untuk kesuksesan akademisnya. Selain itu, membaca dan menulis sejak dini untuk membekali anak sebelum memasuki sekolah formal hal ini senada dengan penyataan Reese, Garnier, Gallimore, dan Goldenberg (2000) yang menyatakan bahwa pengalaman anak berinteraksi dengan literasi sejak dini akan menyiapkan ia mengikuti pembelajaran di sekolah formal.

\section{Aktivitas Literasi Dirumah}

Informan menerapkan kegemaran membaca mulai dari dirinya sendiri dan suami, biasanya mereka sering membaca bersama, bacaan yang sering dibaca adalah buku cerita, 
majalah dan koran. Informan telah mengenalkan anak tentang huruf dan angka pada usia \pm 3 tahun dan pada di usia yang sama, informan juga mengenalkan cara membaca dan menulis kepada anak.

Berdasarkan hasil penelitian, dalam aktivitas yang berhubungan dengan literasi dirumah, Informan mengakui bahwa dirinya telah melakukan kegiatan dirumah dalam memberi contoh anak dalam aktivitas yang berhubungan dengan literasi, semisal ayah dan ibu membaca bersama, maka ketika anak melihat secara terus menerus maka anak akan meniru aktivitas tersebut. Hal ini senada dengan pendapat Burgess (2002) yang menyatakan bahwa literasi di lingkungan rumah secara pasif merupakan "pembelajaran langsung secara modeling" seperti anak-anak melihat orangtua membaca buku tetapi orangtua tidak mengajarkannya secara langsung, anak melihat perilaku alami dari orangtua. Berdasarkan data yang telah dihimpun dari Informan, mayoritas anak telah dikenalkan angka, huruf bahkan cara membaca, mulai usia kira-kira 3 tahun.

Pendapat tersebut senada dengan penyataan bahwa sejak lahir sampai usia 3 tahun anak memiliki kepekaan sensoris dan daya pikir yang sudah mulai dapat menyerap pengalamanpengalaman melalui sensorinya (Theo \& Martin, 2004).

\section{Kelengkapan Bahan Pendukung Literasi Dirumah}

Bahan pendukung literasi dirumah, antara lain berupa buku cerita, alat tulis, mainan yang mendukung literasi dirumah yaitu mayoritas informan menyediakan "malam" serta perangkat elektronik yaitu mayoritas sudah menyediakan smartphone sebagai alat bantu untuk mengenalkan kepada anak kegiatan yang berhubungan dengan literasi. Rata-rata informan hanya menyediakan 1 hingga 5 buah saja, seperti buku cerita, alat tulis, mainan, sehingga anak hanya terbatas dalam mengembangkan kemampuan melalui media yang terbatas.

Hasil penelitian menunjukkan bahwa tersedianya bahan atau peralatan pendukung literasi seperti, tersedianya buku cerita, alat tulis dan smartphone dirumah. Hal tersebut sesuai dengan pernyataan Burgess (2002) literasi di lingkungan rumah secara aktif merupakan keterlibatan orangtua dalam mendukung kegiatan anak-anak yang bertujuan untuk mengembangkan keterampilan berbahasa dan keaksaraan (aktivitas literasi) seperti membaca bersama dan melakukan permainan yang memiliki irama. Dengan fasilitas yang ada, orangtua dapat mengajarkan anak sehingga terbentuk perilaku seperti yang dicontohkan oleh orangtua dengan memanfaatkan fasilitas bahan pendukung literasi yang disediakan.

Dalam penggunaan smartphone kepada anak, hal ini juga didukung oleh penemuan Haugland (2000) juga menemukan bahwa anak usia tiga hingga empat tahun yang sudah terbiasa menggunakan komputer, tablet dan smartphone, menunjukkan kelebihan pada penggunaan bahasa verbal, kemampuan memecahkan masalah, berfikir secara abstrak dan kemampuan merekam dalam memori jangka panjang dibandingkan dengan anak-anak yang tidak menggunakan komputer, tablet dan smartphone.

\section{Kegiatan Yang Biasa Dilakukan Oleh Informan Dan Anak Dirumah}

Informan secara aktif dan rutin melakukan kegiatan untuk mengembangkan kemampuan literasi anak, yaitu dalam kegiatan membaca bersama, menggambar bersama anak, menonton televisi bersama anak, serta menyanyikan lagu anak-anak bersama anak. Frekuensi partisipasi kegiatan tersebut masih bervariasi 2 hingga 7 kali setiap satu minggu. Sementara juga diketahui bahwa informan jarang mengajak anak untuk bermain diluar dari lingkungan rumah, semisal mengunjungi perpustakaan, museum.

Menurut data yang dihimpun peneliti, kegiatan yang biasa dilakukan oleh informan dan anak secara rutin di rumah untuk mendukung berkembangnya kemampuan literasi awal pada anak adalah membaca buku bersama, menggambar bersama, menonton televisi bersama serta menyanyikan lagu anak-anak bersama. Dukungan tersebut senada dengan teori Katz (1997) bahwa anak yang mendapat dukungan dan bantuan yang baik dari orangtuanya akan bisa belajar dan mencapai kemajuan lebih baik dibanding anak yang tidak mendapat dukungan dan bantuan dari orangtuanya. 


\section{Penghambat Dalam Mengajarkan Literasi Dirumah}

Dalam mengajarkan literasi kepada anak, informan menemui beberapa hambatan, yaitu hambatan dalam mengajarkan anak baca-tulis, penyebabnya adalah anak kurang fokus, anak belum memiliki minat untuk diajarkan bacatulis, suasana hati anak sering berubah-ubah, ditemukan pula hambatan yang berasal dari luar anak, yaitu alat tulis sering habis karena digunakan oleh anak, beberapa informan menyatakan tidak memiliki cukup waktu untuk mendampingi anak serta kurang sabar untuk mendampingi anak belajar membaca dan menulis.

Dalam melakukan aktivitas literasi dirumah, hambatan yang sering ditemui oleh informan yaitu saat diajarkan baca-tulis, anak tidak fokus memperhatikan informan, anak belum memiliki minat terhadap tulisan dan bacaan,suasana hati anak sering berubah-ubah, ditemukan pula hambatan yang berasal dari luar anak, yaitu alat tulis sering habis karena digunakan oleh anak, informan tidak memiliki cukup waktu untuk mendampingi anak serta kurang sabar untuk mendampingi anak belajar membaca dan menulis. Beragam hambatan tersebut sesuai dengan teori yang dituliskan Syah (2009) yang menjelaskan bahwa hambatan berasal dari diri anak dan dari keluarga, faktorfaktor yang dapat menjadi penyebab kesulitan belajar dalam diri anak meliputi Inteligensi (IQ) yang kurang baik, faktor emosional yang kurang stabil, aktivitas belajar yang kurang, penyesuaian sosial yang sulit, lama belajar yang tidak sesuai dengan tuntutan waktu belajarnya, keadaan fisik yang kurang menunjang, kesehatan yang kurang baik, pengetahuan dan keterampilan dasar yang kurang memadai atas bahan yang dipelajari serta tidak ada motivasi belajar.

Sementara faktor yang berasal dari keluarga menurut Syah (2009) meliputi kurangnya kelengkapan alat-alat belajar bagi anak di rumah, kurangnya biaya pendidikan yang disediakan orang tua, anak tidak mempunyai ruang dan tempat belajar yang khusus, ekonomi keluarga yang lemah atau tinggi yang membuat anak berlebih-lebihan, kesehatan keluarga yang kurang baik, perhatian orang tua yang tidak memadai, kebiasaan dalam keluarga yang tidak menunjang. Sementara jika dihubungkan dengan pendapatan keluarga informan setiap bulannya, maka didapatkan data bahwa mayoritas keluarga informan memiliki pendapatan kurang dari Rp 1.500 .000 setiap bulannya yang menurut Badan Pusat Statistika pendapatan keluarga tersebut termasuk keluarga dengan pendapatan rendah. Maka jika dihubungkan dengan pendapat Syah (2009) faktor ekonomi keluarga menjadi salah satu faktor yang berpengaruh pada hambatan belajar.|

\section{SIMPULAN}

Berdasarkan hasil penelitian yang telah dilakukan, terdapat beberapa kesimpulan yang dapat diambil oleh peneliti, yaitu literasi di lingkungan rumah pada anak pra sekolah terdiri dari kesadaran orangtua akan pentingnya untuk anak diajarkan kemampuan literasi sejak dini yang terdiri dari kebiasaan orangtua dalam melakukan kegiatan literasi sebagai kegiatan yang dilakukan sehari-hari sehingga aktivitas itu juga diterapkan kepada anak usia pra sekolah, kegiatan yang dilakukan orangtua dan anak dilakukan secara bersama-sama dan interaktif didukung oleh bahan atau kelengkapan alat yang dapat membantu berkembangnya kemampuan literasi pada anak, meskipun demikian, peneliti juga menemukan penghambat dalam mengajarkan anak literasi dirumah.

Kesadaran orangtua atau informan terhadap kemampuan membaca dan menulis sejak usia dini dianggap penting untuk kesuksesan akademik di sekolah formal dikarenakan pada usia dini merupakan usia yang tepat untuk membekali anak dengan berbagai keterampilan seperti pengenalan kata, huruf, gambar.

Penghambatan yang dalam mengajarkan literasi dirumah adalah berasal dari diri anak yang belum memiliki dorongan untuk belajar serta hambatan yang berasal dari lingkungan keluarga, meliputi pendapatan keluarga yang tergolong rendah sehingga Informan mengaku ketersediaan bahan pendukung literasi yang terbatas. Selain itu, kebiasaan keluarga yang tidak mendukung seperti tidak tersedianya waktu yang cukup untuk anak dalam mengajarkan aktivitas literasi juga berpengaruh terhadap ketidaksabaran informan dalam mengajarkan 
anak dikarenakan informan tidak terbiasa dan rutin mengajari anak.

Adapun saran kepeada orangtua, yaitu perlunya ditumbuhkan kesadaran akan pentingnya di biasakan kepada anak untuk dikenalkan gambar, tulisan, huruf sejak dini agar anak terbiasa sejak dini, dan fasilitas yang terkait dengan baca tulis juga perlu di sediakan juga waktu orangtua kepada anak untuk mendampingi dan memberi edukasi mengenai apa yang anak lihat di alam sekitarnya.Peneliti selanjutnya dapat lebih mengembangkan penelitian ini dengan menggunakan metode wawancara, observasi serta catatan pada anak pra sekolah di lingkungan keluarga, yaitu berupa jumlah anak di dalam keluarga, melakukan pemisahan antara ibu yang bekerja dengan ibu yang mengurus rumah tangga, status anak pra sekolah hidup bersama keluarga inti (ayah, ibu, kakak, adik) atau extended family (kakek,nenek, paman,bibi dll). Peneliti berikutnya juga dapat menggali variabel-variabel lain yang mempengaruhi literasi awal.

\section{DAFTAR PUSTAKA}

Agung. (2012, Juli 17). Literasi di Rumah Berpengaruh Kuat Pemahaman Anak Dalam Membaca. Dipetik Oktober 23, 2015, dari Situs Berita Universitas Gadjah Mada: https://ugm.ac.id/id/ berita/4398-literasi.di.rumah.berpengaruh.kuat.pemahaman.anak. dalam.membaca

Burgess, S. R. (2002). Shared reading correlates of early reading skills. Diambil kembali dari Reading Online: http://www.readingonline.org/articles/art_index.asp?HREF= burgess/index.html

Bus, A. G., Van, I., M. H., V. I., \& Pelligrini, A. D. (1995). Joint book reading makes success in learning to read: a meta-analysis on intergenerational transmission of literacy. Review of Educational volume 65, 1-21.

Haugland, S. (2000). What role should technology play in young children's learning? Part 2. Early childhood classrooms in the 21 st century: Using computers to maximize learning. Young Children, 55(1), 12-18.

Hidayat, A. A. (2008). Pengantar Ilmu Kesehatan Anak untuk Pendidikan Kebidanan. Jakarta: Salemba Medika.

Katz, A. (1997). Membimbing Anak Belajar Membaca. Surakarta: Arcan.

Martini, J. (2006). Perkembangan dan Pengembangan Anak Usia Taman Kanak Kanak: pedoman bagi orang tua dan guru. Jakarta: PT Grasindo.

Roberts, J., Jurgens, J., \& Burchinal, M. (2005). The role of home literacy practices in preschool children's language and emergent literacy skills. Journal of Speech, Language, and Hearing Research, 48, 345-359.

Sadr, A. J., Juhari, R., Mansor, M., Esmaeili, N. S. S015). Home Environment a n d Emergent Literacy among Young Children in Iran. Asian Social Science, 11(9), 138-145.

Schmitt, S. A., Simpson, A. M., \& Friend, M. (2011). longitudinal assessment of the home literacy environment and early language. Infant and Child Development, 20(6), 409-431.

Theo, R., \& Martin, H. (2004). Pendidikan Anak usia dini: tuntunan psikologis dan pedagogis bagi pendidik dan orang tua. Jakarta: PT. Gramedia Widiasarana. 